This item was submitted to Loughborough's Research Repository by the author.

Items in Figshare are protected by copyright, with all rights reserved, unless otherwise indicated.

\title{
The neoliberal culturalist nation: voices from Italy
}

\section{PLEASE CITE THE PUBLISHED VERSION}

http://dx.doi.org/10.1111/tran.12132

\section{PUBLISHER}

Wiley / @ Royal Geographical Society (with the Institute of British Geographers)

\section{VERSION}

AM (Accepted Manuscript)

\section{PUBLISHER STATEMENT}

This work is made available according to the conditions of the Creative Commons Attribution-NonCommercialNoDerivatives 4.0 International (CC BY-NC-ND 4.0) licence. Full details of this licence are available at: https://creativecommons.org/licenses/by-nc-nd/4.0/

\section{LICENCE}

CC BY-NC-ND 4.0

\section{REPOSITORY RECORD}

Antonsich, Marco. 2016. "The Neoliberal Culturalist Nation: Voices from Italy". Loughborough University. https://hdl.handle.net/2134/21379. 


\title{
The neoliberal culturalist nation - voices from Italy
}

\author{
Marco Antonsich \\ Loughborough University
}

\begin{abstract}
The impact of neo-liberal globalisation on the nation-state has been extensively studied in terms of politico-economic restructuring and forms of governmentality and securitisation. While the former speaks of a process of de-nationalisation, the latter brings about a re-nationalisation process. In both cases, though, the focus has only been on one component of the nation-state, i.e. the state. The nation has either been treated as a given backdrop or merely ignored. This articles aims to bring the nation back as a way to better contextualise practices of socio-spatial exclusion associated with one particular aspect of neoliberal globalisation, namely international migration. By analysing parliamentary debates in Italy between 1986 and 2014, the article explores the intersections between neoliberalism and cultural essentialism as they conflate in what I call the 'neoliberal culturalist nation'. This construct permits to identify the role that a national culturalist imaginary plays in prompting and justifying governmental practices of securitization, which in turn are implicated in the production of vulnerable and expendable labour force. Moreover, it reveals how a neoliberal workfarist and individualised logic is functional to the 'normalisation' of the foreign immigrant and the reproduction of the national titular group. My argument is that a national culturalist imaginary exists in a mutually reinforcing relation with, rather than in opposition to neoliberalism. Far from keeping nation and state as ontologically distinct or theorising their decoupling, the article points instead to a renewed spatial isomorphism between nation and state which comes indeed to epitomise the very process of current re-nationalisation.
\end{abstract}

\section{Introduction}

Scholarly interest in the impact of neoliberal globalisation on the nation-state seems to have revolved around two main areas: politico-economic restructuring and securitisation. Starting with the mid-1990s, the neoliberal shift associated with globalisation (Larner, 2003) has been studied in terms of the re-scaling of forms of political governance and modes of economic production and capital accumulation (Brenner, 1999; Jessop, 1994; MacLeavy and Harrison, 2010; Sassen, 1996). This re-scaling - the argument goes - has produced a de-nationalisation process, as supra- and subnational scales have become prominent registers in regulating people, goods, and capital.

A decade later, a parallel process of re-nationalisation has also emerged as a new focus of scholarly interest. This has occurred primarily in relation to international migration - being itself a key component of neoliberal globalisation (Sassen, 1998: xxi) - and has been explored through 
discourses and practices of securitisation. As noted by Peck and Tickell (2002), the 'roll-back' of the nation-state in the 1970s has indeed been accompanied by a 'roll-out' in the 1990s, characterised by aggressive state interventions in various aspects of the social domain. As 'law and order' becomes the motto of a new securitising agenda (Bigo, 2002), the national border becomes a key site where state interventions are scrutinised, also in their projection beyond the national territory (Coleman and Stuesse, 2014; Mountz and Hiemstra, 2014; Vaughan-Williams, 2010). Reinforcing, patrolling, surveilling the national border have emerged as common practices among some of the most economically globalised countries, producing a seemingly paradoxical nexus between forms of securitised nationalism and free market transnationalism (Coleman, 2005; Sparke, 2006).

The interplay between de-nationalisation and re-nationalisation offers a useful analytical lens to explore the impact of neoliberal globalisation on the nation-state. Yet, in this interplay I believe something is missing. Both strands of literature, in fact, mostly focus on only one of the two components of the nation-state, namely the state. The nation barely enters the picture. If it does, it is either deployed as a synonym of state or treated as a given, static backdrop against which to analyse state practices. This, I would suggest, is not surprising, since in geography readings of neoliberal globalisation have tended to be informed by either a Marxist political economy approach or a post-structuralist Foucaldian focus on governmentality (Larner, 2003), which both have the state, its power and spatiality as privileged objects of investigation. ${ }^{1}$

This article aims to go a step further and bring the nation back as a way to offer a more articulated account, in particular, of the re-nationalisation process. To be true, the nation has never ceased to be a symbolic register of affection, identity and attachment for people whose spaces have been traversed by re-scaling processes (Antonsich, 2009). Yet, it is exactly for this reason that it is even more surprising that the nation has not figured prominently in scholarship aimed at studying the 'rolling-out' of the nation-state. As a way of filling this gap and drawing on literature which examines discourses of cultural fundamentalism (Stolcke, 1995) or essentialism (Grillo, 2003), the article proposes the concept of 'neoliberal culturalist nation'. The theoretical and analytical purchase 
of this concept does not reside in reiterating the exclusivist thrust of the nation as a cultural formation per se (Smith, 1986), but in exposing how a national culturalist imaginary - i.e., an essentialist understanding of the national culture (Grillo, 2003: 160) - exists in a mutually reinforcing relation with the neoliberal agenda. This perspective goes beyond a reading of the national ethnocultural revival as a reactive opposition to neoliberal globalisation (Castells, 2000; Kymlicka, 2013; Rex, 1996). On the one hand, in fact, it is the 'othering' narrative emanating from the culturalist nation which makes possible the production of immigrants as precarious subjects, functional to the neoliberal search for cheap, disposable labour force (Lewis et al., 2014). On the other hand, the same culturalist nation deploys a neoliberal narrative - imbued with a workfarist and individualised logic (Larner, 2000) - in order to 'normalise' those immigrants who are allowed to exist on the national soil. The neoliberal culturalist nation emerges exactly at this intersection between culturalist narratives of nation and neoliberalism, thus providing terrain for better contextualising public discourses and state practices of socio-spatial inclusion/exclusion in the current age of neoliberal globalisation (Mezzadra and Neilson 2013). Far from keeping nation and state as ontologically distinct or theorising their decoupling, the article points instead to a renewed spatial isomorphism between nation and state which comes indeed to epitomise the very process of renationalisation.

Methodologically, the article relies on content analysis of political debates on immigrationrelated issues held in the Italian Parliament between 1986 and 2014, focusing particularly on right and centre-right political narratives. The choice of Italy as a case study seems particularly suitable, since Italy has rapidly become an immigration country during a time in which the neoliberal agenda has emerged as the hegemonic expression of globalisation (Oliveri, 2012).

The article is structured as follows. In the next section, I will offer a more extensive discussion of the re-nationalisation processes within the context of neoliberal globalisation. I will then introduce the chosen case study and discuss the data collection process. The critical analysis of these data will be articulated around two main sections, which aim respectively to support the case for the 
renewed isomorphism between nation and state and to map the neoliberal and ethno-cultural nexus. The analysis of the parliamentary debates reveals how the conflation of the culturalist and neoliberalist logics operate to make the inclusion/exclusion of immigrants acceptable. In the conclusion, I shall reflect on the limits of the re-nationalisation process and open up space for alternative readings of nation in the age of neoliberal globalisation.

\section{The nation-state between de-nationalisation and re-nationalisation}

Although the term 'neoliberal globalisation' is a shortcut for a complex plurality of politicoeconomic processes (Larner, 2003), scholars generally agree on locating its rise in the passage from a Fordist to a post-Fordist mode of production or, in Jessop's (1994) conceptualisation, from a Keynesian welfare state to a Schumpeterian workfare state. In this passage, the nation-state has experienced a process of de-nationalisation, understood as a re-scaling of regulatory intervention and capital valorisation at sub- and supra-national scales (Brenner, 1999). The new socio-spatial formations which have emerged from this transformation are not only 'glocalised' assemblages (Swyngedouw, 1997), with multiple structurations of "the global inside" (Sassen, 2003: 15), as manifested for instance in the rise of global cities, but also a constellation of numerous spatial scales which "do not converge with one another on the national scale or constitute an isomorphic, selfenclosed national totality" (Brenner 1999: 441).

Accompanying this restructuring in politico-economic terms is also an important societal transformation. An 'active society', formed by individualised subjects responsible for their own wellbeing, is indeed a key feature of the neoliberal agenda (Larner, 2000; Peck and Tickell, 2002; Türken et al. 2015). In this shift from a society of collective citizenship to a society of individualised citizenship (Sparke, 2006), the state plays a crucial role. It is indeed the state that, through its interventionist 'zero tolerance' policies, is instrumental in the construction of the workfarist/activist 
society (Bruff, 2014; Peck and Tickell, 2002; Wacquant, 1999). 'Law and order' emerges as the main securitising narrative regulating the internal space of the neoliberal state (Bigo, 2002) and the national border becomes the key site where this securitising discourse is most visibly staged (Darling, 2011; De Genova, 2013). While the individualised, self-responsible producer-consumer comes to the fore as the mainstream form of subjectivity within this neoliberal state, the dispossessed, vulnerable, hyper-precarious immigrant equally configures another type of neoliberal subjectivity less to the fore, but no less conspicuous (Lewis et al., 2014; Varsanyi, 2008). His [sic] 'illegality' is often read as the direct product of the state (Anderson et al. 2009; Dauvergne, 2008; De Genova, 2002) which, by 'excepting' (Khosravi, 2010) his presence, contributes to the creation of a cheap, scared, and expendable workforce, functional to capital reproduction and accumulation (Bauder, 2008; Coutin, 2010; Hiemstra, 2010). In the formation of both types of subjectivities, but particularly in the latter one, the national border acquires a new centrality and signals an opposite move to the de-nationalisation process observed above. This is also true of the nation as a symbolic register, as signalled by the increasing consensus to nationalist parties in Europe (Wodak, 2013). Yet, as already mentioned, the focus of these studies and particularly of those privileging a governmentality perspective, is the state. The nation is either taken-for-granted or merely absent. When some form of collectivity is evoked, this is usually 'society' rather than 'nation'. The risk, I would argue, is one of producing studies which talks of a state operating in a national vacuum - as if national (hi)stories, representations, and imaginaries did not matter for understanding discourses and practices of border construction and enforcement against the present neoliberal condition.

A closer look at the nation, instead, surfaces in those accounts which read re-nationalisation in terms of a new wave of cultural fundamentalism (Stolcke, 1995) or cultural essentialism (Grillo, 2003). Echoing Taguieff's notion of differential racism, this reading posits cultural differences as incommensurable, thus casting the non-national as perennially foreign within the host society (what Balibar (1991) calls neo-racism). Such a perspective is very relevant for capturing the culturalist 
production of nation (i.e., the use of culture in fixed, essentialised terms), but it does not necessarily contextualise this production within the present wave of economic neoliberalism.

There are a few scholars, though, who have tried to link nation and neoliberalism. Among them, Sharma's (2006) notion of 'home economics' offers important insights. Her home(land) is simultaneously built on a culturalist understanding of nation and a hierarchical spatialisation of subjects unevenly positioned within global capitalism. Home economics creates differentiated identities out of the interplay of culturalist and racialist discourses of nation and hierarchical articulations of class and labour geographies. The end result is the production of "'homelands' that essentially leave the vast majority of the world's migrant peoples homeless" (Sharma, 2006: 4).

Sharma's home economics closely resonates with Walters' (2004) notion of 'domopolitics'. Even in this case, the national home is treated in culturalist terms and imbued with a sense of affectivity, security, and entitlement. Yet, Walters does not elaborate on the links between nation and neoliberalism, as for him domopolitics exists in tension with oikos, i.e. liberal political economy. The interesting point that domopolitics adds to this debate, however, is the taming aspect associated with domus (home), i.e. the will to domesticate those who are perceived to threaten the home.

This latter point is clearly in line with the work by Hage (2000), whose 'white nation' is equally imbued with a culturalist and racialised national imaginary, which constructs white Anglo-Saxon Australians as the titular group exclusively entitled to draw boundaries of socio-spatial inclusion/exclusion. It is this monopoly over the national space which produces and is produced by an exclusivist imagined relationship between the national self and a given territory and which positions the ethnic/racial Other as a disposable object within both this space and its underlining neoliberal economy.

Another important contribution in this direction is Schinkel and van Houdt (2010), who expressly study the link between communitarianism and neoliberalism. They see Dutch cultural norms and values as constructed out of a process of moralisation and responsibilisation of 
citizenship, which demands active participation and contribution on the part of immigrants to successfully acknowledge their national integration (see also Matejskova, 2013).

The present article aims to build on and expand these insights by exploring the intersections between neoliberal globalisation and narratives of nation as they coalesce in what I call the 'neoliberal culturalist nation'. With regard to international migration, the re-nationalisation process is not only about the state and its governmentality practices of controlling, containing and disposing of vulnerable subjects nor a mere ethno-cultural revival opposing neoliberal globalisation. Renationalisation is also about the strengthening of the hyphen which links nation and state, the reinforcement of that conceptual isomorphism which neoliberal globalisation challenges in terms of political governance and modes of economic production. Far from resisting globalisation, the neoliberal culturalist nation is one which tactically deploys some of the neoliberal drivers to reaffirm itself as a rather impermeable ethno-cultural group versus an individualised immigrant subject.

Before illustrating the case study, I should mention that 'nation' in this paper is used not as an analytical or heuristic device, but as a category of practice (Brubaker and Cooper, 2000): nation is what political actors make of it. In this sense, it is not assumed to be a substantive entity, filled with objective markers, but a discursive instantiation, activated situationally to interpret and understand experience (Brubaker, 2006).

\section{The Italian case study}

Italy has become a country of immigration only recently. Although, statistically, this happened in 1973, when immigrants first outnumbered emigrants (Pugliese, 2002), the first considerable inflow took place between 1984 and 1989, when 700-800,000 people entered the country (Zincone, 1998: 48). Besides being a relatively recent phenomenon, immigration to Italy has also been a 
relatively rapid one. On 1 January 2003, the presence of immigrants amounted to 1,549,373 or $2.7 \%$ of the total population. A decade later, on 1 January 2014, the figure was up to 4,922,085 or $8 \%$ of the total population (source: ISTAT http://demo.istat.it/). Between 2003 and 2010, there was an average growth of $12.7 \%$ or 431,000 people a year (Ambrosini, 2013: 139). It is this fact, along with its history of emigration, its small or negative population growth, the existence of a diffuse illegal labour market, the practice of frequent amnesty laws, and a public ill-prepared for the settlement of immigrants, which make Italy - along with Greece, Spain and Portugal - a country representative of the so-called 'Mediterranean model of immigration' (DeMaria Harney, 2006; King and Black, 1997; Pugliese, 2002).

Politically, Italy has experienced a major reshuffling in the early 1990s, after the judicial investigation Mani Pulite wiped out some of the traditional political parties which governed the socalled First Republic (1948-1994), namely the Christian Democrats (DC) and the Socialists (PSI) (Burnett and Mantovani, 1998). In the Second Republic, those parties which survived Mani Pulite have gone through major ideological changes. This is the case of the Communist Party (PCI), which has changed into the present Partito Democratico (PD) - in line with mainstream social-democratic parties in Europe - and the neo-fascist MSI-DN, which has changed into the post-fascist Alleanza Nazionale (AN). The major transformation associated with the Second Republic, though, was the appearance in 1994 of Forza Italia (FI), the centre-right political party led by the tycoon Silvio Berlusconi, which had governed Italy for most of the 2000s (Shin and Agnew, 2008). In 2009, FI and AN merged into Popolo della Libertà (PdL), which was short-living, as in $2013 \mathrm{FI}$ was reconstituted and AN imploded, giving birth to a small political formation (Fratelli d'Italia, Fdl). The other major change associated with the Second Republic was the rise of the Lega Nord (LN) (Agnew, 2000), a regionalist party which has long claimed the independence of the Italian North (Padania), but which under the present leadership of Matteo Salvini has campaigned nationally with an anti-immigration and anti-Europe agenda (Albertazzi and McDonnell, 2015). Since 2013, another major political actor is the Movimento 5 Stelle (M5S), a party created and led by an ex-comedian, Beppe Grillo, whose 
political views defy a clear left/right reading, being characterised, among others, by Euroscepticism, populism, and environmentalism (Bordignon and Ceccarini, 2013).

When it comes to national identity, Italy has often been portrayed as a failed or unaccomplished nation (Graziano, 2010). Various scholars, Italian included, have noted the weak sense of national identity among Italians (Bedani and Haddock, 2000; Galli della Loggia, 1996; Patriarca, 2001). In the well-known study by Putnam (1993), Italians' poor social capital and civic spirit are mentioned to explain this weakness (see also Banfield, 1958). Recently, though, Muehlebach (2012) has shown the existence of a diffuse social capital in the form of volunteer work which, interestingly enough for the scope of this article, spurs from the neoliberal retreat of the welfare state and contributes, in an unwittingly complicitous way, to substantiate this move. Also constantly referred to in the literature is the North-South divide (Schneider, 1998), along with the laxity of the Italian state, since state-building - the argument goes - has only partially succeeded and has been largely detached from nation-building (Gentile, 2010). However, when asked about their feelings of national pride, Italians usually show a percentage higher than the European average (Antonsich, 2009). In 2011, Italy also celebrated the 150th anniversary of its political unification, with one-year long celebrations largely attended by ordinary people and with a rich editorial production (Rossi, 2012).

Data used in this study are political debates on immigration-related issues, held in both the Camera (Lower House) and the Senato (Upper House) of the Italian Parliament, between 1986 and 2014. In 1986, the Parliament approved what is usually considered (Allievi, 2014) as the first immigration law (Law 943/1986). This was then followed in 1990 by the so-called 'Martelli Law' (Law 39/1990) and, eight years later, by the 'Turco-Napolitano Law' (Law 40/1998), both approved by a centre-left majority. Between these two laws, in 1992 the Parliament approved the current nationality law (Law 91/1992). Finally, in 2002, a centre-right majority approved the 'Bossi-Fini Law' (Law 189/2002), which is the immigration law still in force today in Italy. 
Although these are the main legislative acts around which the parliamentary debate analysed in this article revolved, immigration-related issues (e.g., citizenship, integration, border enforcement, education of children of immigrants, etc.) were discussed throughout the surveyed period. These parliamentary debates have been complemented with 15 semi-structured individual interviews conducted by the Author, between April and May 2015, with current political party members responsible for immigration and with some key actors of the past legislatures involved in the drafting of the above-mentioned laws.

I should clarify that my main focus of analysis is not the content of the laws, but the political debates surrounding them. ${ }^{2}$ Moreover, my analysis aims neither to track down which party said what, in an attempt to study Italian party politics per se, nor to present a chronological account of the debate law by law. This is not only an impossible endeavour in the space of a journal article, but also one which would hardly add substantial information, since the themes which emerged earlier in the debate were the same in later debates, although amplified. On the contrary, the aim is to map how the nation has been discursively mobilised facing international migration, with a particular focus on right and centre-right parties. Left and centre-left narratives, instead, depart from the neoliberal culturalist nation (Antonsich 2016); yet, Zincone (2006b) has revealed a coincidence in terms of governmental policies, which equally contributes to immigrants' discrimination (see also Però, 2007; Garau, 2015).

All data were collected in Italian (translations are by the Author) and coded via an analytic induction approach (Crang, 1997) which, echoing grounded theory, relies on the iterative process of going back and forth between original data and theoretical concepts in order to reach successively more abstract categorisations.

\section{Talking nation in the age of migration}


The culturalist nation

"We do not oppose [immigration] for racist reasons, but because if we keep allowing them in, we will produce a massive inflow of extracomunitarian immigrants in Italy and we will face an enormous phenomenon of eradication of this people from their own natural context" (Camera, 20/02/1990: 49101). This passage is from an intervention by MP Rauti, leader of the rightist party MSI-DN during the discussion of the Martelli Law. Recalling his visit to Birmingham, UK, where he saw deprived housing estates "packed" with women and children of immigrant origin, Rauti adds: "I asked myself: but what do these woman and children do here, far away from their land, their habits and traditions, their sky, their climate, far away from anything which constitute the background of a decent communitarian living?" (Ibid.). The idea of the culturalist nation here cannot emerge more clearly. Nation is about roots, the organic relationship between a given people and a given land, which in turn generates a unique culture. The metaphor of eradication reinforces and naturalises this link. As Del Donno (MSI-DN) observes during the same debate: "To transport a tree from Africa to Italy and to transplant it when it has already grown means to sentence it to death" (Camera, 15/02/1990: 48878).

The differentialist imaginary at work in these passages returns in other debates throughout the surveyed period and it was explicitly reasserted in the individual interviews with right-wing parties, like for instance in this quote from an Anonymous representative of the Lega Nord (LN): “Each people has its own culture and tradition and must preserve it [...] because a people without culture is like a tree without roots [...] We did not create this world. God created it, by diversifying it. One cannot unite what cannot be united. It's like trying to unite oil and water. The world is made of nations!" (20/05/2015). The removal of agency in this view helps fixating national cultures in space and time, legitimising the irreconcilability among them and therefore their mutual exclusion. Here and in other interviews and parliamentary debates, nation and diversity stand in opposition. The 
very prefix 'multi' (as in 'multi-cultural', 'multi-ethnic', 'multi-racial') irritates the proponents of this cultural essentialism: "We risk becoming a multi-ethnic and multi-racial nation. Yet, we believe, and I personally believe, that Italy, as it has been for thousands of years, must remain a Christian and a mono-cultural society" (Martinat, MSI - Camera, 15/02/1990: 48845). ${ }^{3}$ The reference to Christianity, made during the debate on the first major immigration law (Martelli Law), introduces already from the beginning of the Italian debate on immigration a theme, i.e. Islamophobia, which is to become more frequent in the following debates. Yet, the point I would like to highlight here is the inner paradox of cultural differentialism. The right to difference, in fact, is not an absolute principle to be defended across time and space, but its defence stops at the national border. Difference is praised as long as it remains confined within this border. The right to difference ceases when a person trespasses their putative national space. "Sure, we want cultural diversity, but we don't want a multicultural society of immigrants; we want foreigners to integrate" (Moro, LN - Camera, 11/07/2002: 55). Interestingly, this statement was pronounced during the debate on the Bossi-Fini Law by an MP of the Lega Nord, a party which, in its campaign for the independence of Padania, has defended more than others the right to regional difference.

The attention to the national border, as expressed throughout the parliamentary debates, at times with colourful expressions such as "frontiere colabrodo" (leaky frontiers) or "frontiere grooviera" (Gruyère frontiers), points to a re-nationalisation process through which the state is called in to protect the (culturalist) nation. In this sense, border enforcement is not merely an act of governmentality, with a state exercising its power over a population and a country (Chauvin and Garcés-Mascareñas, 2012: 254), but the response demanded and legitimised by a nation which envisions a given land, sky, and climate - like in the above passage by Rauti - as 'ours'. A culturalsymbolic entitlement translates into a legal one and cements the alliance between nation and state in the mastering of the national space (Hage, 2000). This in turns produces the spatial exclusion of the 'national Other' - those who are perceived to belong to another national space - or their precarious inclusion, as I shall discuss in the next section. 
The primacy of the culturalist nation in this re-nationalisation process emerges also from the debate on the reform of the nationality law in 1992. Although at this time the demographic change was already at the centre of the political discussion (the Martelli Law was indeed passed in 1990), the citizenship law (91/1992) - still in force today - strengthens the principle of ius sanguinis. ${ }^{4}$ Approved also with the votes of centre-left parties, the law facilitates the acquisition of Italian citizenship for those of Italian descent living abroad, and make naturalisation harder for foreign nationals, rising the residency time from five to ten years. As MP Toth, speaker for the Christian Democrats, observed during the parliamentary debate: "For those who take inspiration from Catholic political thought, the nation comes before the state. The natural society comes before the state. Thus, it is correct that the state acknowledges, to those who are part of this natural society, the right to belong, for him [sic] and his descendants" (Camera, 23/05/1991: 43). Within this culturalist understanding of nation, here also imbued with a religious tone, the state is merely an instrument; it does not have a life in its own. Its actions are the actions of the nation, i.e. the titular group which uses the state to empower itself. Analytically, to attend to this national imaginary is important exactly because it tends to be overlooked in governmentality accounts of states practices. These seem indeed to operate in an abstract space, a sort of national vacuum, thus (re)producing the idea of the state as an autonomous entity, driven by a self-governing logic, detached from both the national context within which it is imbricated and the national people who populate it (Jones, 2007; Mountz, 2003).

The re-nationalisation process is even more apparent when compared with the dominant narrative of the leftist parties (Antonsich 2016). In this case, the national marker is not mobilised to produce cultural and legal entitlement, but it is the shared human condition, like in political liberalism (Rawls, 1993), the exclusive source of rights. Following the well-known Habermasian scheme, the leftists thus point to a de-nationalised or post-national scenario, in which the state is decoupled from the nation (Habermas, 2001). Not surprisingly, this view was vehemently contested in the Parliament by rightist MPs, as for instance in the following intervention on the approval of the 
Turco-Napolitano Law, which besides regulating migratory flows, also provided legally residing immigrants with a series of rights: "Behind this law there is the phenomenal attack of the leftist ideology against a certain type of culture: our culture [...], our identity, our values. [...] I don't know whether our way of life, our identity is better or superior to others. I only say that it is different. I believe that the state must first protect this identity, these values, however they are: better or worse" (Fontan, LN - Camera, 19/11/1997: 112).

A culturalist understanding of nation is clearly not a product of globalisation; yet, in the context of increasing migratory flows, this understanding gains new momentum, leading to a renewed emphasis on the hyphen which links nation and state. This is because globalisation is perceived as a logic of 'up-rooting', while the nationalist logic is narrated as one of 'rooting'. In this sense, the culturalist nation can be read as a localist reaction to feelings of displacement brought about by global demographic and economic changes, as first noted by Castells (2000). Within this context, cultural essentialism become not only a vehicle of otherisation, but also a strategy for reconstituting social unity against feelings of fragmentation brought about by neoliberal reforms of the labour market and welfare system. ${ }^{5}$ Thus, the culturalist nation emerges as unwittingly complicitous with the neoliberal turn.

However, there is something more than juxtaposition. In the next section I wish to explore the ways in which the culturalist nation intersects neoliberal globalisation, in a mutually reinforcing rather than juxtaposing logic. It is in the working of these two logics that the immigrant subject gets caught, by being either excluded or hierarchically inserted in a condition of constant vulnerability.

The neoliberal culturalist nation aka the 'normal' nation

From a culturalist national perspective, the migrant is deviant by definition. In a world of nations where people are rooted to 'their' land, migration is an aberrant form of behaviour in need 
of being fixed (Anderson et al., 2009: 8). It is against this reading of migration as deviance that the culturalist nation is also constituted as a 'normal' nation. As mentioned by the leader of the Lega Nord, in the aftermath of his party's success in the 2015 local elections: "Beyond the polemic that the Lega is ugly, racist, bad, populist and Nazist, we want some equity; some more jobs and some clandestine less. Some normality. There you are: Italy needs normality" (TG5, 01/06/2015, http://www.video.mediaset.it/video/tg5/full/541664/edizione-ore-13-00-dell-1-giugno.html).

When confronted with international migration, normality is far from being a politically neutral concept. It is instead imbued with a cultural mainstream which hardens the national border to keep off those who are perceived to subvert this normality and which normalises the others who accept to be domesticated. While the former logic of socio-spatial exclusion operates via the construction of a 'we' vs. 'them' narrative, which reinforces the deviant features of the out-group, the latter logic of normalisation operates via an individualising narrative, which preserves the primacy of the national 'we' by exactly erasing, in the immigrant, any possible sign of belonging to a cultural 'them'. In both cases, a culturalist national imaginary intersects a neoliberal agenda. In the first case, the cultural deviance of immigrants justifies a different legal regime, one in which 'their' rights do not count as 'our' rights, thus transforming them in a mass of cheap, disposable labour force, essential for the economic competition of a country which wants them exactly as "unwanted" (Hage, 2000: 135). In the second case, the inclusion via normalisation is not only permeated with a culturalist repertoire, but also with a neoliberal one, because being an 'active' contributor to society is the necessary - although never sufficient - condition for inclusion.

Let me illustrate these two positions in the light of the parliamentary debate. The uneven legal treatment of immigrants emerges from the beginning of the discussion on immigration. Six months before the Martelli Law (1990) was passed, a group of immigrants employed illegally in harvesting tomatoes in Villa Literno, a town near Naples, was attacked and one of them killed by an unknown group of people, probably affiliated with the local criminal clan which was involved in their exploitation (Campani, 1993). The Martelli Law, in its attempt to regulate immigration, was also seen 
as a response to this event which had vast public resonance (Zincone, 1998). During the parliamentary debate, the question of the legalisation of undocumented immigrants provoked an animated discussion. The PRI (Republican Party), despite being part of the governing coalition, voted against the law. Among its various justifications, one touched on the equality of rights. In the words of Martino (PRI): "here we have the arrogance of transforming, with a legal act, an immigrant - very often a clandestine - in a subject entitled with civil rights, giving him [sic] those rights which are common to any citizen of our country" (Camera, 21/02/1990: 49289). Similar views were echoed by rightist MPs during the same debate. What emerges here is the permissibility of the state (law) to discriminate against those who are not part of the nation. Clearly, the creation of immigrants as vulnerable subjects, exposed to exploitation and violence, is not a mere act of neoliberal governmentality, but intersects a culturalist understanding of nation.

As a way to better capture the cultural fundamentalism of this view, let's consider, for instance, the following exchange between Mantovani, leader of the extreme left party Rifondazione Comunista, and some MPs of the rightist party AN during the conversion into law of the so-called Decreto Dini (1995), which introduced another regularisation of undocumented immigrants:

Mantovani: "We want a civil Italy in a civil Europe, which could..."

Selva: "We too!"

Mantovani: "We have two different conceptions of civility, dear colleagues of AN [...] I was saying that we want a civil Italy in a civil Europe. Without the contribution, the intelligence of immigrants who came to our country, like our emigrants have been to Belgium, Germany, France and everywhere in the world... [lively protests from MP Alboni]" Chairman: “Honourable Alboni, I call you to order! Honourable Alboni, please sit down! I call you to order!"

Gramazio: "Shame on you!"

Chairman: “Honourable Gramazio!” 
Mantovani: “No, shame on you, dear colleague, because contrary to you I believe that an Italian emigrant and a Tunisian immigrant are the same thing! [Protests from MP Gramazio]" (Camera, 28/11/1996: 8061)

This exchange reveals the emotive reaction of the culturalist nation, which perceives the equivalence made by Mantovani as a moral offence. Italian emigrants and foreign immigrants are culturally and morally incommensurable (Muehlebach, 2012). It is this culturalist differentialism which justifies the legal exclusion operated by the state. Italians come first, as often heard throughout the surveyed period, and the law should protect them in the first instance. As put it by a Lega Nord MP in a parliamentary motion: "We don't believe that a family father who only has one soup dish and gives it to his son is racist, whereas other political forces wish instead to keep the son hungry and give the soup to the neighbour. For us, this would be a degenerated father, not a democratic father. A father who does not think first of his children is a degenerated father and the state, we believe, should act like a good family father" (Fedriga, LN - Camera, 17/06/2014: 78). State and nation are once again united in an organic, naturalising relationship - like father and family, respectively - which allows for the translation of the ethno-cultural primacy into a legal privilege. As the titular group ('the family'), Italians have a pre-emptive right to the resources of the state, following a logic of welfare chauvinism also at work in Sharma's (2006) notion of home economics (see also Ince et al., 2015). Not surprisingly, in 2014, the Lega Nord proposed to revise the Constitution and introduce a differential treatment in terms of social rights so to privilege Italian citizens versus communitarian citizens and third country nationals (Mozione Giorgetti n. 1-00495, Camera, 18/06/2014). At the basis of this initiative and of the culturalist approach to nation more broadly is a zero-sum logic so that any concession, also in terms of rights, to 'them' is perceived as taking something away from 'us'. This is what Volonté and Buttiglione, Christian Democrats (UDC) MPs, in their law proposal titled "Norms for the defence of Italian culture and for the regulation of immigration", call "substantial intolerance", as for them "the respect for minorities translates in a 
non-respect for the majority" (Camera, 31/05/2001: 2). A point observed, among many others, also by a LN MP during the debate on the Turco-Napolitano Law: "[By this law] you indiscriminately open the door to an invasion which, through legal norms and subsequent execution rules, has the declared goal of depriving ourselves, in our home, of our rights!" (Lembo, LN - Camera, 17/11/1997: 9). A win-win situation is hardly conceivable within this perspective, since it would have to assume a condition of equality between majority and minority, in open contrast with the domopolitics (Walters, 2004) of the culturalist nation.

This 'othering' logic, though, does not only operate in culturalist terms. Once again, a neoliberal narrative reinforces this logic by stressing the otherness of a mass of people perceived as not contributing to a nation also conceived in workfarist terms. From the beginning of the parliamentary debate and across the political spectrum, MPs depict immigrants as "desperate", "poor", "weak", and "in need". This characterisation triggers a response of "reception" and "hospitality", also motivated in some parties by a Christian spirit. However, rather than generating the sort of empathy that might lead to a mutual 'inclination', as in Nancy's (1991) notion of clinamen, or to a condition of openness to the arrivant, as in Lash, Derrida and Lyotard (Gressgård, 2010), I would argue that this response reinforces the entitlement of the national group to the national space they occupy as their 'home' (Hage, 2000) and, accordingly, the foreignness of immigrants. Failing to acknowledge their willingness and capacity to contribute to the national economy puts these immigrants in the condition of being a 'burden' to the rest of the national society, "a foreign colony of unemployed who does not produce", as observed by MP Florino (MSI-DN) early in the parliamentary debate (Camera, 30/04/1986: 10). Not being regarded as active members of the society places them outside the space of the 'normal' nation, deviant in their being inactive within a workfarist society and, qua 'irregular', in their being potential criminals. The conflation of the culturalist and neoliberal logics makes their exclusion acceptable, making possible their exploitation by a capital which looks indeed for the 'unwanted' in order to compete in the global race for cheap labour. 
The neoliberal culturalist nation, however, does not only reproduce itself via a process of othering, but also through one of domestication, offering an instantiation of border heterogenisation discussed by Mezzadra and Neilson (2013). In the Italian setting, domestication is discursively operationalised through a national model of 'normality' articulated around the triad 'casa, famiglia, lavoro' (home, family, and work), which clearly imbues the culturalist nation also with a bourgeois, heteronormative, and activist register:

"I would like to point to the other side of the coin, Mr Chairman (because there is always another side of the coin) [...] when one is in Italy, is rooted, is integrated, is married, has children, works... I am talking about a worker of the IP [gas station] of Fiorenzuola (Piacenza), who has been in Italy for 15 years, has a wife, children and works in our country: [Italian] citizenship has not yet been granted to him. This hurts my sensitivity, because when one has naturalised himself, is incorporated, works, has a family, lives here, he has a right to citizenship" (Tassi, AN - Camera, 21/02/1990: 49256).

This passage is from an MP of the rightist party AN who, in other interventions, in line with his party, adopted a sustained narrative of othering in relation to immigrants. Yet, in this case, the normalisation of an individualised immigrant into a family-work model overcomes his foreignness and generates feelings of acceptance. In this context, 'family' is not a generic, neutral notion, but is loaded with a culturalist meaning, as for instance illustrated by another representative of AN, Landi di Chiavenna, during the debate on the Bossi-Fini Law: "The model of society we want to build is based on valuing family, also the families of foreigners, but real families, founded on communion of intents and spirit, not those based on deception and violation of the law. [...] No more counterfeiting, no more families based on laws, habits and costumes which cannot be welcomed within our legal system!" (Camera, 04/06/2002: 21). This passage reveals two important points. First, the importance of family as a sacred principle or, in the words of Volonté (UDC), as "an Italian moral 
and civic quality" which imbues the nation (Camera, 04/06/2002: 16). Second, the cultural distance between this 'normal' family and the family "inspired by a Koranic principle", for which De Corato (AN) reckons it is not possible to talk in terms of family law (Senato, 20/11/1996: 37). Not only is this latter family out of place in the legal body of the nation, but also in its everyday spaces, being characterised as a sort of exotic spectacle that triggers amused puzzlement, like in the following intervention by Rubinacci (MSI) during the debate on the Martelli Law: "Between January 7 and 14, in Rimini, there was a queue of Blacks [negri] from Piazza Cavour till the Municipality's offices. Well, I witnessed this episode: a Black [negro] showed up who had two wives and seven children! The Council had problems to register them. Think about such an event: a Black, with two wives and seven children!" (Camera, 22/02/1990: 49548).

Together with family, and intimately imbricated with it, housing is another dimension through which normalisation operates. In the view of Del Donno (MSI): "the house is the nest where love naturally springs and marriage is sanctified by God and men" (Camera, 21/02/1990: 49250). In this view, house/home, family, and God collapse into one single national imaginary of normalisation. To inhabit "a house worth this name" (Valli, LN - Senato, 19/11/2008: 3) is therefore another condition through which the individual immigrant is domesticated into a 'normal' nation, sanitised from the deviant practice of those "who maybe rent the flat declaring to be a family of two and then, in a matter of days, they become a family of ten", making the house a "filthy" and "degraded" place (Goisis, LN - Camera, 28/11/2006: 5). It is worth noting that, since Law 94/2009 (passed by the Berlusconi government), house's size and hygiene are legal requisites for the immigrant to file a request of family reunion. Thus, the material space of the house acquires a symbolic value that helps drawing the national boundary of inclusion/exclusion.

More than others, though, work emerges as the primary condition operating the 'normalisation' of the individual immigrant. Present from the beginning of the parliamentary debate, work becomes, with the Bossi-Fini Law (2002), the essential condition for the existence of the immigrant on the national soil. Under this law, still in force today, the residency permit is only issued on the basis of 
the immigrant having a legal job. Before the immigrant could exist as a person, a job has to exist. If the job terminates, also the person terminates. There is no right to exist on the national soil in the absence of an active contribution to the national welfare. This is the key condition for putting forward any claim, as already heard, for instance, in the debate on the Martelli Law: "We should do so that immigrants, when they put their feet on Italy, have a job; only so they could make legitimate claims for housing, healthcare and education" (Caria, PSDI - Camera, 15/02/1990: 48834). Also in the unified text concerning the reform of the nationality law (2005), this active contribution is explicitly mentioned, as the foreign national demanding naturalisation should demonstrate "a salary sufficient for their maintenance" and "evidence of not having received public benefits during the three years before the request of naturalisation" (Camera, A.C. 204, 16/05/2005: 17).

Driven by a neoliberal workfarist logic, this position sets the terms of the immigrant's incorporation on a sort of private contract. In fact, in 2009, under the Berlusconi government, the Parliament passed Law 94/2009 which expressly introduced a 'contract' between the State and the immigrant aimed at his/her integration. Failing to meet the requirements of this contract would lead to expulsion of the immigrant (Gargiulo, 2012). In a neoliberal logic of individual autonomy, the immigrant is the sole responsible for his/her own incorporation, while the state abdicates to its welfarist obligations. ${ }^{6}$ The state (law) also stops operating as the guarantor of public liberties and becomes a censor which scrutinises the terms of this private engagement. The normalisation of the immigrant passes through their domestication into an active neoliberal subject, stripped of any cultural reference to an out-group: “We accept [...] the regularisation [sanatoria] for whom is in Italy and has full title to stay because he works, produces, pay taxes, like any other citizen, Italian or foreign. Then, he can be white, black, or yellow: we don't care about the colour of the skin of the communitarian or extracomunitarian citizen; we care that he is 'regular' and that he resides in Italy to work and produce" (Martinat, MSI-DN - Camera, 20/02/1990: 49143). This view from an MP of the rightist party MSI-DN, during the debate on the Martelli Law, suggests two main points. First, as aptly observed by Hage (2000: 90), immigrants do not merely exist, but they are allowed to exist. It is 
the national titular group, the group self-entitled to (master) the national space which grants this permission, thus empowering itself with a form of 'governmental belonging' which constitutes the immigrant as a passive object of government whose national belonging is always conditional (Hage, 2000: 17, 45). Second, this permission is not given to a full person, but only to a working individual, often deprived of a moral standing by the titular national group, as aptly illustrated by Muehlebach (2012). Recognition of other aspects of that person does not matter. It actually should not matter for not challenging the titular group in its possession of the national space and the mainstream narrative associated with it.

In the few cases in which the diversity of immigrants is taken into consideration, like for instance in the debate on the construction of a mosque in Colle Val d'Elsa (Tuscany), this operates via an individualising logic aimed at de-triggering the disruptive power of the group: "The key solution is to address directly the single Muslim, going around the obstacle, namely the Muslim associations, against which the previously cited models [English and French] have clashed, leading to a failure" (Paoletti Tangheroni, FI - Camera, 11/12/2006: 8). The culturalist nation responds to the 'foreign' threat by mobilising an individualising strategy aimed at fragmenting the out-group and its collective claim so to better controlling it.

Taken together, 'casa, famiglia, lavoro' allows for the domestication of the immigrant into both a culturalist and neoliberal mainstream functional to the preservation of the national titular group. Yet, this normalisation process is only apparent, it only gives an appearance of normality, as it is a necessary, but never sufficient condition of full inclusion. This point echoes Mezzadra and Neilson's (2013) insightful argument about the heterogeneisation of borders, which defies the binary inclusion/exclusion and points instead to a condition of differential inclusion of subjects never fully included or excluded. The existence of the culturalist nation prevents full inclusion, as the immigrant is always hierarchically positioned within this nation. It offers a semblance of 'rootedness' to those who, deep inside the national culturalist imaginary, are casted as 'uprooted', i.e. out of place. This 
view emerges explicitly, among others, in the reform of the nationality law proposed by MPs of right and centre-right parties (PdL, LN) in 2006:

"It is very different the position of the citizen iure sanguinis, who belong to a community by birth, from the position of a foreigner who acquire citizenship iure legis. This latter is received in bona fide by a community and whenever commits a serious crime he violates a duty of loyalty, on which the acquisition of citizenship relies" (Camera, proposal n. 1744, 29/09/2006: 2)

Citizenship is always a concession, never an objective right, thus suggesting the important ways in which citizenship also conjures up the nation form (Bryne, 2012; Fortier, 2013). The naturalised citizen is never to be as equal as the Italian citizen. The persistence of the culturalist nation also pervades citizenship as prevents immigrants to become full citizens. It is in this sense that the nation offers the essential lens to understand state governmentality practices. The persistence of the neoliberal culturalist nation presides over the othering of the 'irregular' immigrants and the normalising of the 'regular' immigrant, but between these two positions there is a very thin (and farcical) line, as the latter is only an apparent condition of inclusion.

\section{Conclusion}

In the passage from a Fordist to a post-Fordist globalised world, the nation-state has experienced a de-nationalisation process, since sub- and supra-national scales have emerged as concurrent registers to articulate economic, political, and social processes. Yet, particularly when globalisation is read in terms of international migration, there are also signs of a re-nationalisation process, which reinforces the hyphen between nation and state. 
The present article has illustrated this latter process for the case of Italy and its political elites. As observed by various scholars (Castells, 2000; Kymlicka, 2013; Rex, 1996), re-nationalisation is often casted in oppositional terms to globalisation. This is also true for Italy, as its politicians discursively mobilise the nation in terms of a closed, rooted, culturalist community that the state has to protect against the up-rooting logic of globalisation. Yet, there is something more than this simple action-reaction mechanism. The analysis of Italian parliamentary debates also shows how this culturalist rendition of nation intersects a neoliberal agenda. This happens in two ways. First, the othering narrative emanating from the culturalist nation is functional to the very (re)production of a mass of 'others' who, exactly because of their otherised foreignness, are deprived of a full moral standing, thus making their potential exploitation by neoliberal capital more acceptable (Chauvin, 2012; Muelebach, 2012). Second, the normalisation of those immigrants who accept to be domesticated (i.e. tamed in their foreignness) not only exposes a culturalist, but also a neoliberal discourse. Acceptance - however provisional it might be - is indeed conditional to compliance with a national mainstream articulated in both culturalist (e.g., home, family) and neoliberal (work) terms. It is this neoliberal culturalist nation which prompts and justifies governmentality practices aimed at controlling, regulating, or excluding the presence of foreign bodies on the national space.

Although these insights emerge from a specific case study, it is not hard to see them apply also to other contexts, as when it comes to international immigration re-nationalisation seems ongoing across the world - from the decision of some European countries to build 'anti-immigration' fences to South Africa's recent wave of xenophobic attacks against foreign workers and Malaysia's and Thailand's increasing uneasiness with Rohingya and Bangladeshi refugees (just to name a few examples recently in the news).

The key question which remains to be addressed is whether this is the only possible reading of nation in the age of globalisation. If so, it is not surprising that many scholars, among which Sharma (2006: 139), have called "to de-nationalise our imaginations and our geographies", as nationalism is essentially a spatial politics of apartheid (Sharma, 2006: 138). Similarly, Closs Stephens (2013) calls 
for a political imagination which can coalesce around urban everyday encounters rather than national identities.

Yet, my reading of the parliamentary debates also seems to point to another direction. Throughout these debates, the dominant position of the leftist parties, as mentioned in the article, has been one of de-coupling nation and state. This post-national attitude uses the universal principles of political liberalism to generate inclusivity beyond culturalism. However, this does not mean that culture is expunged altogether. There are indeed various instances in which this postnational stance gives way to a national imaginary which accommodates diversity within a national repertoire of historical and cultural resources. The question, therefore, might not necessarily be to move beyond nation, but to map those instantiations which lead to a different national imaginary, one not exclusively filled with cultural essentialism/fundamentalism, but with liberal political principles (Antonsich 2016). Implicit in this quest is the suggestion that there might be nothing per se regressive in the idea of nation, but like any other social category also nation can be filled with exclusivist discursive and practices. To assume instead that this is always the case stands for a postulate rather than a fact.

\section{References}

Agnew J 2000 The road to Padania: the Northern League and Italian regionalism International Journal of Urban and Regional Research 24 227-231

Albertazzi D and McDonnell D 2015 Populists in power Routledge, London

Allievi S 2014 Immigration, religious diversity and recognition of differences Identities 21 724-737

Ambrosini M 2013 'We are against a multi-ethnic society': policies of exclusion at the urban level in Italy Ethnic and Racial Studies 36 136-155

Anderson B Sharma N and Wright C 2009 Why no borders? Refuge 26 5-18 
Antonsich, M. 2009 National identities in the age of globalization National Identities 11 281-299

Antonsich, M. 2016. International migration and the rise of the 'civil' nation Journal of Ethnic and Migration Studies http://dx.doi.org/10.1080/1369183X.2016.1155980

Antonsich M and Matejskova T 2015 Immigration Societies and the Question of 'the National' Ethnicities 15 495-508

Balibar E 1991 Is There a 'Neo-Racism'? In Balibar E and Wallerstein I eds Race, Nation, Class Verso, London $17-28$

Banfield EC 1958 The moral basis of a backward society Free Press, New York

Bauder H 2008 Neoliberalism and the economic utility of immigration Antipode 40 55-78

Bedani G and Haddock B eds 2000 The Politics of Italian National Identity. University of Wales Press, Cardiff

Bigo D 2002 Security and immigration: toward a critique of the governmentality of unease. Alternatives 27 63-92

Bordignon F and Ceccarini L 2013 Five stars and a cricket. Beppe Grillo shakes Italian politics. South European Society and Politics 18 427-449

Brenner N 1999 Globalisation as Reterritorialisation: The Re-scaling of Urban Governance in the European Union Urban Studies 36 431-451

Brubaker R 2006 Nationalist politics and everyday ethnicity in a Transylvanian town Princeton University Press, Princeton

Brubaker R and Cooper F 2000 Beyond 'identity' Theory and Society 29 1-47

Bruff I 2014 The rise of authoritarian neoliberalism Rethinking Marxism 26 113-129

Burnett SH and Mantovani L 1998 The Italian Guillotine Rowman\&Littlefield, Lanham

Byrne B 2012 A local welcome? Narrations of citizenship and nation in UK citizenship ceremonies. Citizenship studies 16 531-544

Campani G 1993 Immigration and racism in southern Europe: the Italian case. Ethnic and Racial Studies 16 507-535 
Castells M 2000 Information age Blackwell, Oxford

Chauvin S and Garcés-Mascareñas B 2012 Beyond Informal Citizenship International Political Sociology 6 241-259

Closs Stephens A 2013 The Persistence of Nationalism Routledge, London

Coleman M 2005 US statecraft and the US-Mexico border as security/economy nexus. Political Geography 24 185-209

Coleman M and Stuesse A 2014 Policing Borders, Policing Bodies in Jones R. and Jones C. eds. Placing the Border in Everyday Life Ashgate, Aldershot 69-124

Coutin SB 2010 Confined within: National territories as zones of confinement. Political Geography 29 200-208

Crang M 1997 Analyzing qualitative materials in Flowerdew R and Martin D eds Methods in human geography Longman, Edinburgh 183-196

Cuttitta P 2014 Mandatory Integration Measures and Differential Inclusion Journal of International Migration and Integration, 1-14

Darling J 2011 Domopolitics, governmentality and the regulation of asylum accommodation. Political Geography 30 263-271.

Dauvergne C 2008 Making people illegal Cambridge University Press, Cambridge

De Genova N 2002 Migrant 'illegality' and deportability in everyday life Annual Review of Anthropology 31 419-447

De Genova N 2013 Spectacles of migrant 'illegality': the scene of exclusion, the obscene of inclusion. Ethnic and Racial Studies 36 1180-1198

DeMaria Harney N 2006 The alternative economies of emigration and immigration, the Real and the constitution of Italian nation spaces. Mobilities 1 373-390

Einaudi L 2007 Le politiche dell'immigrazione in Italia dall'Unità a oggi Laterza, Roma-Bari Fortier AM 2013 What's the big deal? Naturalisation and the politics of desire Citizenship Studies, 17 $697-711$ 
Galli della Loggia E 1996 La morte della patria Bari, Laterza

Garau E 2015 Politics of National Identity in Italy Routledge, London

Gargiulo E 2014 Dall'inclusione programmata alla selezione degli immigrati Polis 27 221-250

Gentile E 2010 Né stato né nazione Laterza, Roma-Bari

Graziano M 2010 The failure of Italian nationhood Palgrave, London

Gressgård R 2010 Multicultural dialogue Berghahn, New York

Grillo R 2003 Cultural essentialism and cultural anxiety. Anthropological Theory 3 157-173

Habermas J 2001 The Postnational Constellation MIT, Cambridge

Hage G 2000 White nation Routledge, London

Hiemstra N 2010 Immigrant "illegality" as neoliberal governmentality in Leadville, Colorado Antipode $4274-102$

Ince A Featherstone D Cumbers A MacKinnon D and Strauss K 2015 British Jobs for British Workers? Negotiating Work, Nation, and Globalisation through the Lindsey Oil Refinery Disputes Antipode 47 139-157

Jessop B 1994 Post-Fordism and the State in Amin A ed Post-Fordism Blackwell, Oxford 251-279 Jones R 2007 People-States-Territories Blackwell, Malden

Khosravi S 2010 An Ethnography of Migrant 'Illegality'in Sweden: Included Yet Excepted? Journal of International Political Theory 6 95-116

King R and Black R eds 1997 Southern Europe and the new immigrations Sussex Academic Press, Brighton

Kymlicka W 2013 Neoliberal Multiculturalism? in Hall PA and Lamont M eds Social Resilience in the Neo-Liberal Era Cambridge University Press, Cambridge 99-126

Larner W 2000 Neo-liberalism: Policy, ideology, governmentality Studies in political economy 63 5-25 Larner W 2003 Neoliberalism? Environment and Planning D 21 509-512

Lewis H Dwyer P Hodkinson S and Waite L 2014 Hyper-precarious lives Migrants, work and forced labour in the Global North Progress in Human Geography 1-21 
MacLeavy J and Harrison J 2010 New state spatialities: perspectives on state, space, and scalar geographies Antipode 42 1037-1046

Matejskova T 2013 “But One Needs to Work!”: Neoliberal Citizenship, Work-Based Immigrant Integration, and Post-Socialist Subjectivities in Berlin-Marzahn Antipode 45 984-1004

Mezzadra S and Neilson B 2013 Border as method Duke University Press, Durham

Muehlebach A 2012 The moral neoliberal Chicago University Press, Chicago

Mountz A 2003 Human Smuggling, the Transnational Imaginary, and Everyday Geographies of the Nation-State Antipode 35 622-644

Mountz A and Hiemstra N (2014). Chaos and crisis: Dissecting the spatiotemporal logics of contemporary migrations and state practices Annals of the Association of American Geographers 104 382-390

Nancy JL 1991 The inoperative community University of Minnesota Press, Minneapolis

Oliveri F 2012 Migrants as activist citizens in Italy Citizenship Studies 16 793-806

Patriarca S 2001 Italian neopatriotism: debating national identity in the 1990s. Modern Italy 6 21-34

Però D 2007 Inclusionary rhetoric/exclusionary practices Berghahn, New York

Peck J and Tickell A 2002 Neoliberalizing space. Antipode 34 380-404

Pugliese E 2002 L'Italia tra migrazioni internazionali e migrazioni interne il Mulino, Bologna

Putnam RD 1993 Making Democracy Work Princeton University Press, Princeton

Rawls J 1993 Political liberalism Columbia University Press, New York

Rex J 1996 National identity in the democratic multi-cultural state Sociological Research Online 1

Rossi M 2012 Una sola moltitudine Rubbettino, Roma

Sassen S 1996 Losing Control? Columbia University Press, New York

Sassen S 1998 Globalization and its discontents New Press, New York

Sassen S 2003 Globalization or denationalisation? Review of International Political Economy, 10 1-22

Schinkel W and Van Houdt F 2010 The double helix of cultural assimilationism and neo-liberalism The British Journal of Sociology 61 696-715 
Schneider J ed 1998 Italy's 'Southern Question' Berg, Oxford

Sharma N 2006 White nationalism, illegality and imperialism in Hunt K and Rygiel K eds

(En)gendering the war on terror Ashgate, Aldershot 121-143

Sharma NR 2006 Home economics University of Toronto Press, Toronto

Shin ME and Agnew JA 2008 Berlusconi's Italy Temple University Press, Philadelphia

Smith AD 1986 The Ethnic origins of nations Blackwell, Oxford

Sparke MB 2006 A neoliberal nexus: Economy, security and the biopolitics of citizenship on the border Political Geography 25 151-180

Stolcke V 1995 Talking culture: new boundaries, new rhetorics of exclusion in Europe Current anthropology 36 1-24

Swyngedouw E 1997 Neither global nor local: 'glocalisation' and the politics of scale in Cox KR ed Spaces of Globalization Guilford Press, New York 137-166

Tintori G 2009 Fardelli d'Italia Carocci, Roma

Türken S Nafstad HE Blakar RM and Roen K 2015 Making Sense of Neoliberal Subjectivity Globalizations (ahead-of-print) 1-15

Varsanyi MW 2008 Rescaling the "alien," rescaling personhood: Neoliberalism, immigration, and the state Annals of the Association of American Geographers 98 877-896

Vaughan-Williams N 2010 The UK border security continuum: virtual biopolitics and the simulation of the sovereign ban Environment and Planning D 28 1071-1083

Wacquant L 1999 How penal common sense comes to Europeans: notes on the transatlantic diffusion of the neoliberal doxa European Societies $1319-352$

Walters W 2004 Secure borders, safe haven, domopolitics Citizenship Studies 8 237-260

Wodak R ed. 2013 Right-wing populism in Europe Bloomsbury, London

Zincone G 1998 Illegality, enlightenment and ambiguity South European Society and Politics 3 45-82

Zincone G 2006a Familismo legale Laterza, Roma-Bari 
Zincone G 2006b The making of policies: Immigration and immigrants in Italy Journal of Ethic and

Migration Studies 32(3) 347-375

\section{Acknowledgments:}

I am grateful to John Harrison, Michael Hoyler, Tatiana Matejskova, Enrico Gargiulo and three anonymous reviewers for useful comments. Many thanks also to Roberta Petrillo whose collaboration proved essential in the data collection process. I am also in debt to the Editors of Transactions for carefully reading my manuscript and offering useful editorial assistance. This work was supported by the European Commission under Grant PCIG13-GA-2013-618470.

\footnotetext{
${ }^{1}$ Work in critical population geography, migration studies, and ethnic and racial studies adopt alternative frameworks; yet, even in this case, the tendency has been to eschew the nation as the main focus of investigation (Antonsich and Matejskova, 2015).

${ }^{2}$ For a critical analysis of immigration laws, see Gargiulo, 2014; Einaudi, 2007; Allievi, 2014; Cuttitta, 2014. For the citizenship law, see Zincone, 2006a; Tintori, 2009.

${ }^{3}$ It is worth recalling that Berlusconi, while being Prime Minister, affirmed in 2006: "We don't want Italy to become a pluriethnic, pluricultural country; we are proud of our culture and traditions" (Corriere della Sera, 28/03/2006,

http://www.corriere.it/Primo Piano/Politica/2006/Notizie/Politiche2006/articoli/immigrati.shtml).

${ }^{4}$ In October 2015, a bill aiming at easing the naturalization for children of immigrants was approved by the Camera and is now pending at the Senato.

${ }^{5}$ I am grateful to an anonymous reviewer for suggesting this point.

${ }^{6} \mathrm{I}$ am grateful to another anonymous reviewer for suggesting this point.
} 